\title{
Representation of Lymphocytes in Sinonasal Tissue of Chronic Rhinosinusitis Patients
}

\author{
Luh Putu Lusy Indrawati ${ }^{1}$, Vita Arfiana Nurul Fatimah², and Osman Sianipar ${ }^{3}$ \\ ${ }^{1}$ Department of Ear Nose and Throat, Faculty of Medicine, Public Health and Nursing, Universitas \\ Gadjah Mada, Radiopoetro Building $3^{\text {rd }}$ floor, Jalan Farmako, Sekip Utara, Yogyakarta, 55281, \\ Indonesia \\ ${ }^{2}$ Faculty of Medicine, Public Health and Nursing, Universitas Gadjah Mada, Jalan Farmako, Sekip \\ Utara, Yogyakarta, 55281, Indonesia \\ ${ }^{3}$ Department of Clinical Pathology and Laboratory Medicine, Faculty of Medicine, Public Health \\ and Nursing, Universitas Gadjah Mada, Radiopoetro Building $5^{\text {th }}$ floor, Jalan Farmako, Sekip \\ Utara, Yogyakarta, 55281, Indonesia
}

\section{Abstract}

Chronic rhinosinusitis is divided into nasal polyp subtype and non-nasal polyp subtype. Among those subtypes, there are different histopathologic patterns. One of the criteria of the histopathological parameter is inflammatory cells pattern in sinonasal tissue which can be assessed by counting lymphocytes in sinonasal tissue. This study aims to

Corresponding Author: Vita Arfiana Nurul Fatimah vita.arfiana@gmail.com

Received: 10 November 2018 Accepted: 6 January 2019 Published: 10 March 2019

Publishing services provided by Knowledge

(c) Luh Putu Lusy Indrawat et al. This article is distributed under the terms of the Commons Attribution License, which permits unrestricted use and redistribution provided that the original author and source are credited.

Selection and Peer-review under the responsibility of the UASC Life Sciences 2016 Conference Committee. describe the representation of lymphocytes in sinonasal tissue of chronic rhinosinusitis patients. This descriptive observational study included 21 chronic rhinosinusitis patients in otolaryngology clinic of Dr. Sardjito Hospital Yogyakarta, Indonesia who had undergone endoscopic sinus surgery during the year 2013 and fulfilled the criteria. Information about sample subtypes was obtained from medical record while data about lymphocytes count in sinonasal tissue was obtained from counting microscopically using the light microscope in 5 zigzag consecutive high-power fields (HPF). Nasal polyp subtype was found in 20 (95.24 \%) cases while nonnasal polyp subtype was in 1 case (4.76\%). Representation of lymphocytes in nasal polyp subtype was higher than that in non-nasal polyp subtype. Mean, standard deviation, median, minimum count, and maximum count of tissue lymphocyte in nasal polyp subtype were 78 cells/HPF, 46 cells/HPF, 65 cells/HPF, 25 cells/HPF, and 207 cells/HPF respectively while tissue lymphocyte count in non-nasal polyp subtype was 21 cells/HPF. Using Hellquist classification, the histopathological characteristics of nasal polyp subtype were described. The highest count of tissue lymphocytes was found in Hellquist type IV. Within one disease entity, two subtypes, and four histological types, chronic rhinosinusitis has a highly variable amount of tissue lymphocytes.

Keywords: Chronic rhinosinusitis, Histopathology, Lymphocyte(s), Nasal polyps, Hellquist classification. 


\section{Introduction}

Chronic rhinosinusitis is chronic inflammation of nasal mucosa and paranasal sinus(es) for at least 12 consecutive weeks. It commonly occurs in adult and elderly age, particularly within $30 \mathrm{yr}$ to $69 \mathrm{yr}$. Its prevalence increases with age. Women experience chronic rhinosinusitis more often than men [1].

The prevalence of chronic rhinosinusitis in the global population is estimated as much as $14 \%$ [2]. In the United States, based on data of the 2012 National Health Interview Survey (NHIS), $12.1 \%$ of the total population was diagnosed with rhinosinusitis [3]. Data from 2013 Ministry of Health of Republic Indonesia showed that the disease was in $25^{\text {th }}$ place of first 50 most common disease patterns or around 102817 outpatients in hospital [4, 5]. During January to August 2005, as many as 300 of 450 rhinologic patients (69 \%) was diagnosed with chronic rhinosinusitis in Rhinologic Division of ENT Department Ciptomangunkusumo Hospital Jakarta, Indonesia. In Hasan Sadikin Hospital Bandung, Indonesia during January to December 2007 there were 168 chronic rhinosinusitis patients (64.29\% of all rhinologic patients) [6]. In Dr. Sardjito Central Hospital Yogyakarta, Indonesia during 2000 to 2006 , the frequency of chronic rhinosinusitis patients was 2.5 \% to $4.6 \%$ [7] while during 2006-2007 there were 118 chronic rhinosinusitis patients (42 $\%$ of all rhinologic patients) [6].

Pathogenesis of chronic rhinosinusitis is a chronic inflammation with polyfactorial causes. The underlying process is an alteration in many spectrums such as histopathology, inflammatory cells pattern and T-cell, remodeling, eicosanoid and IgE production, microorganism, and epithelial barrier malfunction [8]. The pathologic process of paranasal sinuses in chronic rhinosinusitis results from long-term inflammation process of nasal and sinusal mucoperiosteum layer and is the continuity of acute inflammation. Theoretically, the long-running pathologic process of mucosa may result in proliferation, granulation tissue formation, or granulomatous inflammation in the sinusal mucosa which in turn develop into sinusal mucosa thickening [9].

Based on the endoscopic finding, chronic rhinosinusitis may be accompanied by a nasal polyp or not. Histopathologically, chronic rhinosinusitis with nasal polyp is known to have eosinophilic inflammation pattern despite the existence of non-eosinophilic variation, with plasma cell number proportional to polyp degree. Chronic rhinosinusitis without nasal polyp is known to have neutrophilic inflammation pattern although the study by Polzehl et al., demonstrated that neutrophil number in nasal polyp and nonnasal polyp chronic rhinosinusitis is not significantly distinctive [10]. However, lymphocyte involvement in chronic rhinosinusitis pathology was not assessed in that study. 
Lymphocyte infiltration in nasal and paranasal sinusal mucosa is one of the histopathological signs of chronic inflammation in chronic rhinosinusitis. This finding may have both prognostic value to long-term clinical outcome and predictive value to the persistence of disturbing symptoms after application of definitive therapy sinus endoscopic surgery [11]. Furthermore, representation of lymphocyte number which depicts its distribution may show inflammation pattern in chronic rhinosinusitis. The pattern may affect the disease prognosis, asthma comorbidity, surgical approach, recurrence, and pharmacological management [8].

\section{Materials and Methods}

\subsection{Materials}

The sinonasal tissue sample was obtained during an endoscopic procedure. Then it was processed into preparations on an object glass size $(75 \times 25 \times 1) \mathrm{mm}$, fixated and preserved with $10 \%$ formalin, stained with Hematoxylin-Eosin, and covered with a $(22 \times 22 \times 0.16) \mathrm{mm}$ cover glass. Tissue lymphocyte was counted on preparations which observed using a binocular light microscope. Data of chronic rhinosinusitis subtype (with or without polyp) were obtained from medical record of patients who undergo the endoscopic procedure.

\subsection{Methods}

This research was a descriptive observational study which involved rhinosinusitis patients of ENT-HN polyclinic in Dr. Sardjito Central Hospital Yogyakarta during January to December 2013. Diagnosis of rhinosinusitis was based on Task Force criteria as follows experienced symptoms for 12 wk or more duration, diagnosed with a nasal polyp or non-nasal polyp chronic rhinosinusitis based on the endoscopic finding, had undergone endoscopic surgery to obtain a sinonasal tissue sample, and agree to participate as the subject of study. Patients were excluded from the study if having sinonasal and leukocyte malignancy and incomplete medical record. Lymphocyte count was done in five randomly selected consecutive high-power fields in the zigzag direction in sinonasal tissue preparations using a light microscope with 400 times magnification then the average number was calculated to obtain lymphocyte count per high power 
field (HPF). Histopathological observation and tissue lymphocyte counting were performed subjectively by the first author and another undergraduate student to ensure the validity.

\subsection{Data analysis}

Descriptive analysis was carried out using IBM SPSS Statistics $22^{\text {nd }}$ version for Windows ${ }^{\circledR}$ Operating System. Categorical data of chronic rhinosinusitis subtype were presented in percentage to the number of the sample which then showed the proportion of nasal polyp and nonnasal polyp chronic rhinosinusitis patients. Numerical data of tissue lymphocyte average number per HPF were presented in mean, deviation standard, median number, minimum number, maximum number, then further group based on its subtype. In each subtype group, mean, deviation standard, median number, minimum number, and maximum number were calculated.

\section{Results}

Twenty-one chronic rhinosinusitis patients met the criteria consisted of 20 cases (95.24\%) of chronic rhinosinusitis with nasal polyp and one case of chronic rhinosinusitis without nasal polyp were included (Fig. 1). Among chronic rhinosinusitis with nasal polyp cases, there were two cases of inverted papilloma. Histological appearance of chronic rhinosinusitis with a nasal polyp, without nasal polyp, and inverted papilloma is shown in Fig. 2.

An average number of lymphocyte in preparations was 76 cells/HPF with deviation standard of 47 cells/HPF. Lymphocyte count laid between 21 cells/HPF and 207 cells/HPF. Lymphocyte median number was 60 cells/HPF. Its distribution in chronic rhinosinusitis tissue preparations can be seen in Fig. 3 where lymphocytes mostly were found in lamina propria and rarely in the epithelium. Tissue lymphocytes count of both nasal polyp and nonnasal polyp group is summarized in Table 1.

TABLE 1: Descriptive analysis of tissue lymphocytes count in chronic rhinosinusitis.

\begin{tabular}{|l|c|c|c|c|c|c|}
\hline Subtype & $n(\%)$ & Mean & SD & Median & Min & Max \\
\hline Non-polyp & $1(4.76 \%)$ & 21.20 & - & 21.20 & 21.20 & 21.20 \\
\hline Polyp & $20(95.24 \%)$ & 78.37 & 46.32 & 64.90 & 24.60 & 206.80 \\
\hline Total & $21(100.0 \%)$ & 75.65 & 46.83 & 60.20 & 21.20 & 206.80 \\
\hline
\end{tabular}




\section{Chronic Rhinosinusitis}

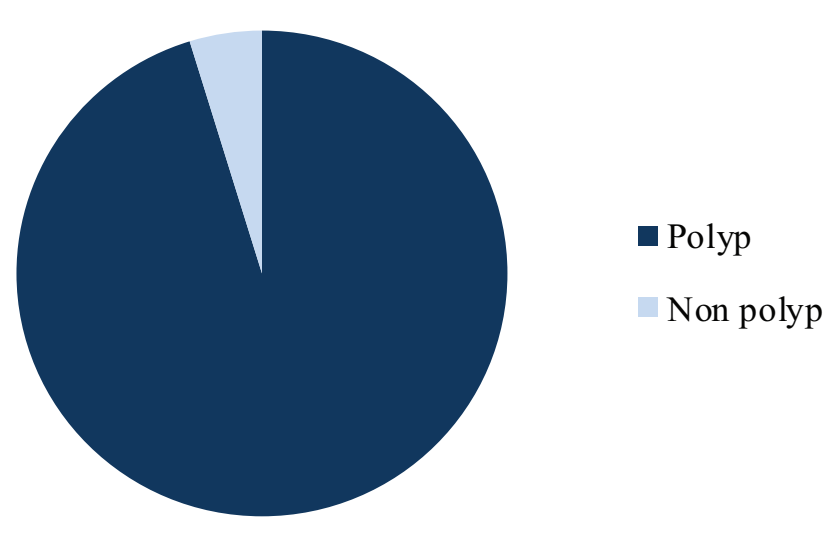

Figure 1: Percentage of chronic rhinosinusitis subtypes.

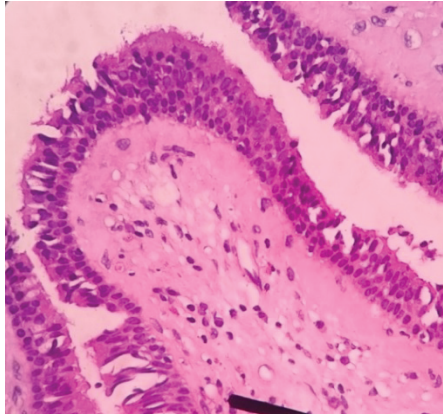

(a)

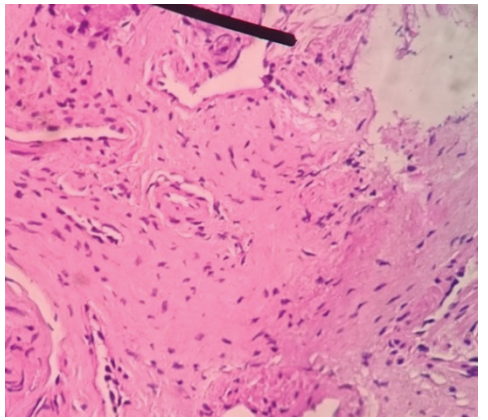

(b)

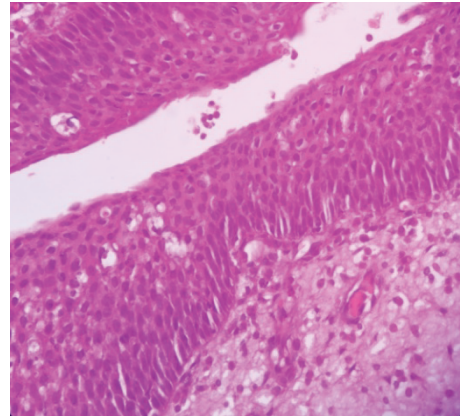

(c)

Figure 2: Histopathology of chronic rhinosinusitis sinonasal tissue (a) polyp, (b) nonpolyp, and (c) inverted papilloma (H\&E; 400X).

The nasal polyp group was further grouped based on the classification method invented by Hellquist [12]. Grouping was performed based on histopathological characteristics into edematous type (Hellquist I), fibroinflammatory type (Hellquist II), seromucinous gland hyperplasia type (Hellquist III), and atypical stroma type (Hellquist IV). In this study, there was one case of nasal polyp which was unable to be grouped based on Hellquist classification because the observed tissue was adjacent skin tissue instead of nasal mucosa tissue thus total nasal polyp cases included in Hellquist classification were 19 cases. By subjective histopathological assessment, seven cases (36.8 \%) were grouped as Hellquist type I, seven cases (36.8\%) were Hellquist type II, three cases (15.8\%) were Hellquist type III, and two cases (10.5\%) were Hellquist type IV (Fig. 4). Histological appearance of each Hellquist types is shown in Fig. 5. The highest mean of tissue lymphocytes count was found in Hellquist type IV, i.e. 170.8 cells/HPF, whereas the lowest one, i.e. 55.06 cells /HPF found in Hellquist type I (Table 2). 


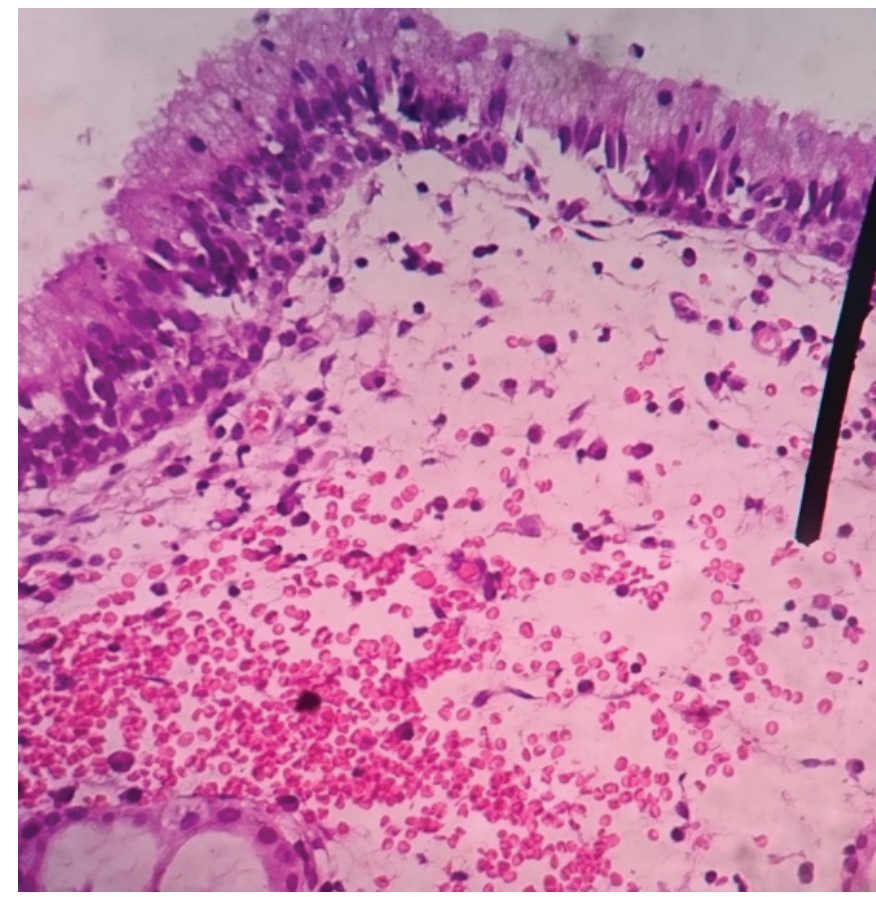

Figure 3: Lymphocytes looked more abundant in lamina propria than epithelium (H\&E, 400x).

\section{Nasal Polyp}

$\square$ Hellquist I $\square$ Hellquist II $\square$ Hellquist III $\quad$ Hellquist IV

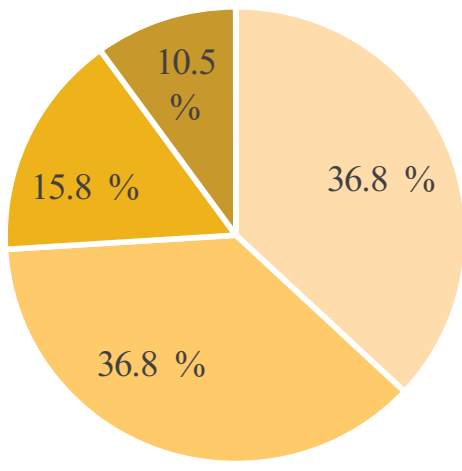

Figure 4: Histopathological types of nasal polyp in chronic rhinosinusitis.

TABLE 2: Tissue lymphocytes count in nasal polyp group of chronic rhinosinusitis.

Hellquist
II
III
IV
Total

\begin{tabular}{|c|}
\hline$n(\%)$ \\
\hline $7(36.8 \%)$ \\
\hline $7(36.8 \%)$ \\
\hline $3(15.8 \%)$ \\
\hline $2(10.5 \%)$ \\
\hline $19(100 \%)$ \\
\hline
\end{tabular}

\begin{tabular}{|c|}
\hline Mean \\
\hline 55.06 \\
\hline 87.06 \\
\hline 68.80 \\
\hline 170.80 \\
\hline 81.20 \\
\hline
\end{tabular}

\begin{tabular}{|c|}
\hline SD \\
\hline 25.07 \\
\hline 37.92 \\
\hline 24.27 \\
\hline 50.91 \\
\hline 45.77 \\
\hline
\end{tabular}

\begin{tabular}{|c|}
\hline Median \\
\hline 50.60 \\
\hline 90.40 \\
\hline 60.20 \\
\hline 134.80 \\
\hline 69.60 \\
\hline
\end{tabular}

\begin{tabular}{|c|}
\hline Min \\
\hline 28.20 \\
\hline 36.60 \\
\hline 50.00 \\
\hline 134.80 \\
\hline 28.20 \\
\hline
\end{tabular}

Max
90.80
143.40
96.20
206.80
206.80




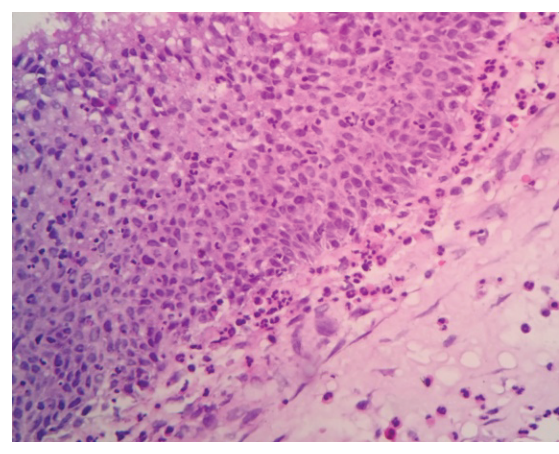

(a)

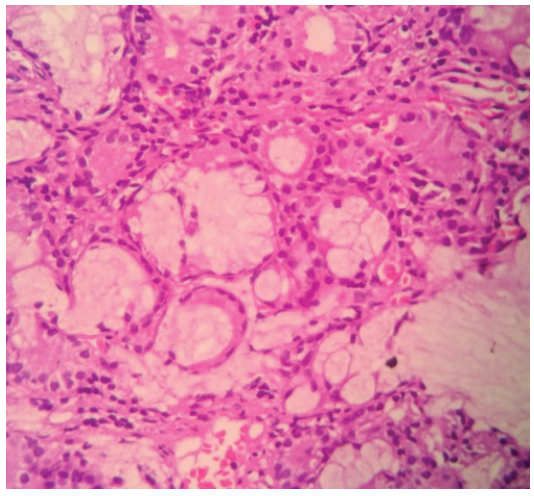

(c)

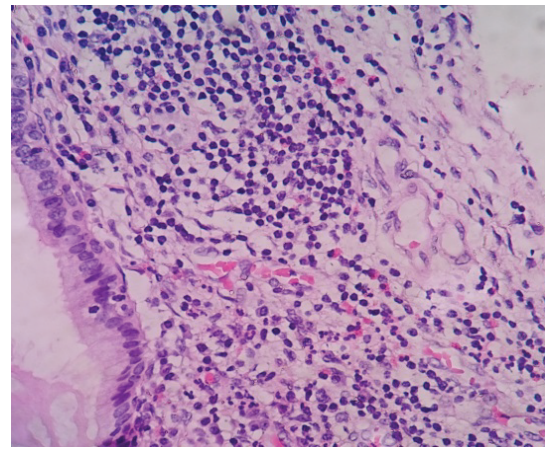

(b)

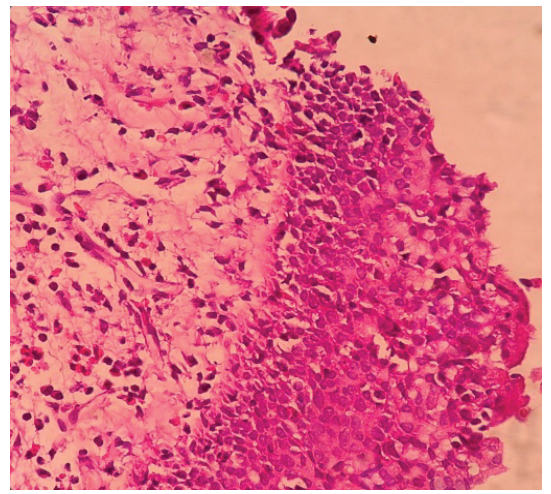

(d)

Figure 5: Histopathology of nasal polyp in chronic rhinosinusitis based on Hellquist classification (a) edematous type, (b) fibroinflammatory type, (c) seromucinous gland hyperplastic type, and (d) atypical stroma type (H\&E x400).

\section{Discussion}

Chronic inflammation in chronic rhinosinusitis is a secondary process resulting from local immune dysfunction as a defect of epithelial barrier integrity and of inflammatory response regulation to foreign antigen 13 which may be precipitated by persistent stimulus or dysregulation of endogenous anti-inflammation mechanism which in the normal state manage to coordinate resolution [14].

Histologically, chronic inflammation correlates with the presence of lymphocytes, macrophages, and also eosinophil and basophil in certain conditions, and blood vessel proliferation, fibrosis, and tissue necrosis [15]. Activation of lymphocytes determines which type of lymphocyte to be recruited as well as the type of inflammation to occur along with a contribution from other inflammatory cells through cytokine-mediated cell communication [16].

Lymphocyte dominance in $90.5 \%$ chronic rhinosinusitis tissue preparation and eosinophil cells dominance in the rest $9.5 \%$ were found in subjective scanning of 
tissue inflammatory cells profile. This finding corresponded with chronic inflammation characteristic [16].

One of the underlying mechanisms of difference in histopathological appearance is Thelper cells population heterogeneity in which the subset domination may determine the type of inflammation. Edematous appearance correlates with T-helper 2 cell-mediated inflammatory environment. In that type of inflammation, expression of FoxP3 in T regulatory cell decreases which in turn causes reduction of tumor growth factor beta-1 (TGF$\beta 1)$ protein level and extracellular matrix destruction. Fibrosis appearance correlates with adequate T-regulatory cell function which increases TGF- $\beta 1$ protein level and causes tissue collagen deposition. 8

Chronic inflammation may manifest in rhinosinusitis as nasal polyp which served as different phenotype from chronic rhinosinusitis without nasal polyp in endoscopic finding. In this study, nasal polyp cases were 20 fold times nonnasal polyp case. It suggests that patients receiving endoscopic surgical therapy were mostly those who had a nasal polyp. Surgical therapy is indicated in cases failed to medication therapy or in cases requiring extensive polyposis therapy [17]. Factors contributing to many surgical cases coming from the nasal polyp group are a common failure of medication therapy and persistent inflammation resulting from obstruction of ostiomeatal complex by the nasal polyp.

This study showed that nasal polyp group had greater tissue lymphocytes average count than a nonnasal polyp. However, the mean difference was not significant because of the unequal sample size between 2 groups. Lymphocytes count in nasal polyp group had large standard deviation which suggested very vast lymphocytes count within 1 group. Tissue lymphocytes count alone cannot be used to differentiate two phenotypes of chronic rhinosinusitis because lymphocytes infiltration can always be found in tissue with chronic inflammation. Also, it requires combination with other histopathological signs such as other inflammatory cells count (eosinophils, neutrophils, mast cells, macrophages, and plasma cells), the presence of basal membrane thickening, tissue remodeling pattern (edematous or fibrosis), and bone structure alteration. Assessment of lymphocytes differentiation using either immunohistochemistry or flow cytometry is also necessary to elicit underlying inflammatory pattern because both phenotypes have different inflammatory pattern even though other factors such as race may also play a role.

A nasal polyp is a chronic inflammatory condition of nasal and paranasal sinus mucosa membrane in the form of edematous mass raised from inflamed mucosa and forming a stalked mass. Massive edematous characteristic in a nasal polyp is resulted from 
plasma leakage because of loose endothelial cells [18]. The nasal polyp can be further classified based on various criteria in which one of them is Hellquist classification [17, 19]. The classification is based on morphological characteristics of histopathological findings. Hellquist type I (eosinophilic or edematous polyp) has characteristics of edematous stroma with many eosinophils and mast cells, goblet cells hyperplasia, and basal membrane thickening. Hellquist type II (fibroinflammatory polyp) is characterized by a distinct inflammatory infiltrate with lymphocytes predominance, without edematous stroma nor goblet cells hyperplasia. Hellquist type III (polyp with seromucinous gland hyperplasia) is characterized by the enormous amount of seromucinous gland and duct structure in the edematous stroma. Hellquist type IV (polyp with atypical stroma) has characteristic of the presence of bizarre and atypical stromal cells which appear irregular and hyperchromatic.

Further histopathological classification of the nasal polyp was carried out in this study because of the dominance of nasal polyp cases in the sample size. The classification was based on the most relevant findings, which were the most dominant ones. Couto et al. mentioned that more than one histological pattern might be present in 1 single polyp which could lead to adequate sample characterization difficulty [17].

Hellquist type I cases were as many as Hellquist type II cases and they were the majority of the total cases, followed by Hellquist type III, then Hellquist type IV. Meanwhile, a study done by Couto et al., in Brazil figured out that Hellquist type I was the majority (65 cases, 73 \%), followed by Hellquist type II (16 cases, $18 \%$ ), Hellquist type III (6 cases, $6.7 \%$ ), and Hellquist type IV (two cases, $2.3 \%$ ) [17]. Another study performed by Souza et al., with a sample size of 17 cases unveiled that fibroinflammatory polyp has the most number of cases (14 cases) followed by fibrotic polyp ( 2 cases), and polyp with gland hyperplasia (one case) with no case of eosinophilic polyp [20]. These different findings might be influenced by geographical difference such as race, medication behavior, and therapy status at the time of biopsy. In the study carried out Souza et al., all patients were known to be in either topical or systemic corticosteroid therapy at the time of biopsy [20] while in the study carried out by Couto et al., patients were not on any medication (topical or systemic corticosteroid, antihistamine, anti-leukotriene, or antibiotics) for at least 30 $\mathrm{d}$ before the biopsy [17]. Meanwhile, in this study, patients' ongoing therapy status was unknown.

Hellquist type IV cases had the greatest number of the tissue lymphocyte average count, but it was also diverse. There was a probability of overlapping number in this type and Hellquist type Il because of the similar basic nature of both types (only differed by the presence of atypical stroma in Hellquist type IV). On the other hand, this diversity might 
be the consequence of a few numbers of cases belong to this type. Tissue lymphocyte count in Hellquist type II was allegedly correlated to fibroinflammatory characteristics through the diversity was also substantial enough. In Hellquist type III, the small count of tissue lymphocytes might result from the crowded stroma by the hyperplastic glands which made lymphocytes were more rarely found in the stroma. Tissue lymphocytes count in Hellquist type I showed that despite its highly variable count, tissue lymphocyte count tended to be low in edematous stroma particularly in the presence of eosinophil dominance.

Descriptive analysis (Table 2) showed the diverse lymphocyte count distribution in each Hellquist nasal polyp type. It might happen because normalization to exclude outliers was not performed which was secondary to small sample size.

Random selection of view field without considering abundant lymphocytes infiltration area might also contribute to influence the result because the scanty lymphocytes infiltration area would make the small count. In this matter, view field selection in the epithelial area above basal membrane (especially in hyperplastic epithelium) and stroma would result in a relatively small number of lymphocytes because inflammatory cells tended to infiltrate basal membrane and lamina propria. Kanai et al. in Lacroix et al., stated that topical steroid therapy was known to reduce lymphocytes number in nasal polyp tissue [19]. Referring to previous statement, patients' status therapy needs to be considered to minimize diversity.

\section{Conclusions}

Among 21 chronic rhinosinusitis patients who underwent endoscopic surgery found 20 cases (95.24 \%) were nasal polyp cases. Tissue lymphocytes count was highly variable within either one disease entity, two subtypes, or 4 nasal polyp histopathological types. The count in nasal polyp subtype was higher than that in non-nasal polyp subtype of chronic rhinosinusitis patients. The highest count was found in Hellquist IV, then followed by Hellquist II, Hellquist III, and Hellquist I.

\section{Acknowledgments}

The authors would like to thank the director Dr. Sardjito Hospital who has permitted to conduct this study. Acknowledgments also go to dr. Dewiyani Indah Widasari, SpPA., Ph.D. who have given valuable input in this study. The author also expressed gratitude 
to the patients who have been willing to participate as research subjects and to all those who have given support to this study.

\section{References}

[1] Budiman BJ, Rosalinda R. Bedah sinus endoskopi fungsional revisi pada rinosinusitis kronis. [Surgical sinus endoscopy revision function in chronic rhinosinusitis]. Repository Universitas Andalas;2014.p. 1. [in Bahasa Indonesia]. [Online] from http: //repository.unand.ac.id/18398/ [Accessed on 2015 May 24].

[2] Perić A, Gaćeša D. Etiology and pathogenesis of chronic rhinosinusitis. Vojnosanitetski Pregled 2008;65(9):699-702. https://www.ncbi.nlm.nih.gov/pubmed/18814507

[3] Blackwell DL, Lucas JW, Clarke TC. Summary health statistics for U.S. adults: National Health Interview Survey, 2012, National Center for Health Statistics. Vital and Health Statistics 2014;10(260):121-122. https://www.ncbi.nlm.nih.gov/pubmed/24819891

[4] Multazar A, Nursiah S, Rambe A, Harahap IS. Ekspresi cyclooxygenase-2 (COX-2) pada penderita rinosinusitis kronis. [Cyclooxygenase-2 (Cox-2) expression on crinic rinosinusitis patients]. ORLI 2012;42(2):96-103. [in Bahasa Indonesia]. http://www. orli.or.id/index.php/orli/article/view/25

[5] Arivalagan P, Rambe A. Gambaran rinosinusitis kronis di RSUP Haji Adam Malik pada tahun 2011. [Description of chronic rhinosinusitis in RSUP Haji Adam Malik in 2011]. E-Journal FK-USU 2013;1(1):1. [in Bahasa Indonesia]. [Online] from https://jurnal.usu.ac. id/index.php/ejurnalfk/article/view/1342 (2013) [Accessed on 2015 May 24].

[6] Multazar A. Karakteristik penderita rinosinusitis kronis di RSUP H. Adam Malik Medan Tahun 2008. [Characteristics of patients with chronic rhinosinusitis in RSUP H. Adam Malik Medan Year 2008]. [Thesis]. Universitas Sumatera Utara, Medan;2011.p. 2. [in Bahasa Indonesia]. https://id.123dok.com/document/download/lzgw1p7y

[7] Harowi MR, Soekardono S, Djoko R BU, Christanto A. Kualitas hidup penderita rinosinusitis kronis pasca-bedah. [Quality of life for chronic rhinosinusitis patients post-surgery]. CDK 187 2011;38(6):429-434. [in Bahasa Indonesia]. http://www.kalbemed.com/Portals/6/09_187Kualitas\%20hidup\%20penderita\% 20Rinosinusitis\%20Kronik\%20Pasca\%20Bedah.pdf

[8] Van Crombruggen K, Zhang N, Gevaert P, Tomassen P, Bachert C. Pathogenesis of chronic rhinosinusitis: Inflammation. The Journal of Allergy and Clinical Immunology 2011;128(4):728-732. https://www.ncbi.nIm.nih.gov/pubmed/21868076

[9] Setiadi M. Analisis hubungan antara gejala klinik, lama sakit, skin prick test, jumlah eosinofil dan neutrofil mukosa sinus dengan indeks lund-mackay CT scan sinus paranasal penderita rinosinusitis kronis. [Analysis of the relationship between 
clinical symptoms, duration of illness, skin prick test, eosinophil count and sinus mucosa neutrophils with lund-mackay index CT scan of paranasal sinus chronic rhinosinusitis]. [Thesis]. Semarang Universitas Diponegoro, Semarang (2009). p. 2-3. http://eprints.undip.ac.id/24724/1/M._Setiadi.pdf

[10] Polzehl D, Moeller P, Riechelmann H, Perner S. Distinct features of chronic rhinosinusitis with and without nasal polyps. Allergy 2006;61:1275-1279. https:// www.ncbi.nlm.nih.gov/pubmed/17002702

[11] Baudoin T, Kalogjera L, Geber G, Grgić M, Čupić H, Tiljak MK. Correlation of histopathology and symptoms in allergic and non-allergic patients with chronic rhinosinusitis. European Archives of Otorhinolaryngology 2008;265:657-661. https: //www.ncbi.nlm.nih.gov/pubmed/18004580

[12] Hellquist HB. Histopathology. Allergy and Asthma Proceedings 1996;17(5):237-242. https://www.ncbi.nlm.nih.gov/pubmed/8871736

[13] Chin D, Harvey RJ. Nasal polyposis: An inflammatory condition requiring effective anti-inflammatory treatment. Current Opinion in Otolaryngology and Head and Neck Surgery 2013;21:23-30. https://www.ncbi.nlm.nih.gov/pubmed/23172039

[14] Zhang LP, Lin L, Zheng CQ, Shi GY. T-lymphocyte subpopulations and B7-H1/PD1 expression in nasal polyposis. The Journal of International Medical Research 2010;38(2):593-601. https://www.ncbi.nlm.nih.gov/pubmed/20515572

[15] Meltzer EO, Hamilos DL. Rhinosinusitis diagnosis and management for the clinician: a synopsis of recent consensus guidelines. Mayo Clinic Proceedings 2011;86(5):427443. https://www.ncbi.nlm.nih.gov/pmc/articles/PMC3084646/

[16] Kumar V, Abbas AK, Aster JC. Robbins and Cotran Pathologic Basis of Disease. 9th ed. Philadelphia: Elsevier Saunders; 2015:93-97. https://studentconsult.inkling.com/ read/robbins-cotran-pathologic-basis-disease-kumar-9/chapter-3/inflammationand-repair

[17] Couto LGF, Fernades AM, Brandão DF, de Santi Neto D, Valera FCP, Anselmo-Lima W. Histological aspects of rhinosinusal polyps. Brazilian Journal of Otorhinolaryngology 2008;74(2):207-212. https://www.ncbi.nlm.nih.gov/pubmed/18568198

[18] Kirtsreesakul V. Update on nasal polyps: Etiopathogenesis. Journal of the Medical Association of Thailand 2005;88(12):1966-1972. https://www.ncbi.nlm.nih.gov/ pubmed/16519003

[19] Lacroix JS, Zheng CG, Goytom SH, Landis B, Szalay-Quinodoz I, Malis DD. Histological comparison of nasal polyposis in black African, Chinese and Caucasian patients. Rhinology 2002;40(3):118-121. https://www.ncbi.nlm.nih.gov/pubmed/12357710

[20] Souza BB, Serra MF, Dorgam JV, Sarreta SMC, Melo VR, Anselmo-Lima WT. Polipose nasossinusal: Doença inflamatória crônica evolutiva. Revista Brasileira 
de Otorrinolaringologia 2003;69(3):318-325. [in Portuguese].. http://www.scielo.br/ scielo.php?script=sci_arttext\&pid=S0034-72992003000300004 